\title{
Symbolic action and organizational resources \\ acquisition and exploitation
}

Prof. Eng. Karolina Mazur, University of Zielona Góra,

Faculty of Economics and Management, Poland, ORCID: 0000-0003-1430-8754.

\section{Introduction}

The problem of symbolic actions in management sciences was raised at the end of the last century (for example: Gioia, Chittipeddi, 1991; Hart, 1992; Singer, 1994; Westphal, Zajac, 1994; Westphal, Zajac, 1998) mainly as a result of the introduction of the concept of capital symbolic by P. Bourdieu to the theory of social science (1986; 1993, after: Swartz, 1998). Symbolic capital was awarded as a form of capital by P. Bourdieu, which legitimizes other forms of capital: economic and social capital (Bourdieu, 1986). P. Bourdieu's theory is not strictly related to organization but only to the field which may arise on its grounds and taking into account its social environment (footnote), however, many studies have recently appeared which transfer P. Bourdieu's theory to the ground organizational sciences by referring to the concept of symbolic capital directly (for example: Gergs, 2003; Fuller and Tian 2006; De Clercq and Voronov, 2009 and others) and indirectly, by introducing the concept of symbolic action and symbolic management (Austen and Kapias, 2016; Lueg and Nielsen 2015, Mazur 2014; Markóczy et al., 2013; 
Rodrigue et al., 2013 ; Perez-Bartes et al., 2012; Jamali, 2010; Kim et al. 2007; Boiral, 2007; Christmann and Taylor, 2006).

The basic idea of symbolic action in an organization is communication with stakeholders to legitimize organizational activities (Ashforth and Gibbs 1991; De Clercq and Voronov 2009). Stakeholders, both external and internal, provide the resources of the organization and can both support its effective operation and limit it to a certain extent. The impact of individual organization decisions on a wide range of external and internal stakeholders is now an unquestioned phenomenon. Therefore, these stakeholders are looking for opportunities to influence the decision-making process of economic and public organizations through various external pressures. Stakeholders enforce the adoption of certain management rigors, which are then adapted by organizations in the form of specific procedures, codes of ethics or formal documents. Due to the diversity of stakeholders, their diverse interests and influences, it is difficult to satisfy all parties, if at all possible. This provides space for the organization to carry out symbolic management activities communicating the organization's adaptation to the expectations of stakeholders but to some extent separate from substantive management. In this way, the phenomenon of symbolic decoupling appears, which is one of the elements of the so-called "The dark side of symbolic management" (Crilly et al. 2016, Mazur 2014, King et al. 2005).

In relation to organization, this concept is described by such theoretical approaches as: agency theory and steward theory, theory of planned behavior (Donaldson and Davies, 1991, Ajzen 1991, pp. 179-211) and a wide range of concepts regarding organizational culture and problems related to CSR (for example: Donia et al. 2019).

As mentioned earlier, the organization communicates to external and internal stakeholders through symbolic management the fact that it will adapt its decisionmaking system to their expectations and does so because the stakeholders provide resources (financial and personal) and affect the efficiency of exploiting these resources. This article is intended to determine the relationship between the organization's symbolic activities and the ability to acquire resources and their efficient exploitation.

This goal will be achieved through a review of available literature in the databases of reviewed articles (Czakon, 2011). Limiting this methodology can sometimes be too superficial treatment of the topic, however, the advantage is its comprehensiveness and that's why the author used this approach. This methodology also makes it possible to determine the maturity of the research field, which can be considered as an additional purpose of the study. 
The following criteria were primarily adopted as the basis for assessing the maturity of the area: research comprehensiveness (are individual elements of the research areas evenly and in a balanced way analyzed), maturity of research tools (have appropriate constructs been developed, methods of their analysis, including structural analysis) and possibilities future research development.

The study included articles contained in the databases of electronic magazines: Proquest, Ebsco, Wiley, Jstor, Elsevier and Emerald. All articles containing the keywords: symbolism, symbolic management, symbolic capital, symbolic action, symbolic value, symbolic value creation, symbolic violence, which were scientific and reviewed articles, were accepted for analysis. 457 articles were obtained during the first analytical iteration (first, rough selection). Then (iteration 2) all articles that did not relate to management issues and doublets were rejected. 73 articles were obtained during this iteration. In the next iteration (third), articles were identified that related to the problem of organizational resources. There were 36 articles that were analyzed in terms of scientific added value and limitations because the basic benefit of this type of analysis is finding a research niche.

Among the analyzed works, 12 were conceptual articles and 24 research articles.

\section{The essence of the symbolic capital of an organization}

The symbolic capital of an organization in the literature is considered in two ways. Part of the narrative concerns the concept of P. Bourdieu and transfers it to the organization. Problems undertaken within this trend are primarily the problem of legitimacy (example: Kang and Park 2016), the problem of symbolic power (example: Harrington et al. 2015) and the related problem of symbolic violence (example: Tomlinson et al. 2013).

The term 'symbolic capital was defined by P. Bourdieu as one of many forms of capital and defined as respect, honor, prestige, recognition that legitimizes social positions (Bourdieu, 1986 p. 57). Symbolic capital refers to one's own reputation and values perceived by others. This value and the strength that accompanies this assessment by others is built over time (Bourdieu, 1993, p. 37 after: Fuller and Tian 2006, p. 288). Symbolic capital determines the degree of prestige or honor obtained through social practices, valued as a source of power obtained through the transformation of economic, social or cultural capital through socalled distinctive practices (Bourdieu, 1993 after: Burri, 2008, p. 37). According to R. Kerr and S. Robinson (2015), symbolic capital can be understood as acting as 
an additional form of capital (Bourdieu, 1994; Swartz, 1997, pp. 92-93; Kerr and Robinson, 2015, p. 704) or as a type of meta - capital, which "obtains from the successful use of other capital" (Kerr and Robinson 2015, p. 704). The concepts related to this concept are the concept of symbolic power and symbolic violence. Symbolic power is defined as the power through which people see and believe in some visions of the world, and not others. "Symbolic power is the power to make things with words. It is only if it is true, that is, adequate to things, that description makes things. "(Bourdieu, 1989, p. 23). Symbolic violence is defined as "violence against a social agent with his participation" (Bourdieu and Wacquant, 1992, p. 272). Symbolic violence is not perceived as a violent control system but the system of functioning based on it and its effects are treated as natural and thus are more easily accepted. In this way there is a process of hidden domination, which causes people to accept processes harmful to them (Agyemang and Broadbent 2015, pp. 1020, 1024).

According to Convay et al. (2017, p. 1022): ,the powerful possessors of symbolic capital become the wielders of symbolic power, and thus of symbolic violence", enabling them to impose meanings as legitimate while concealing the arbitrary power relations that are the basis of its force.

Within these concepts, issues such as the role of leader (in the context of power and symbolic violence) and problems related to the topic of gender are raised. Analyzes of social mechanisms are carried out, which are initiated by symbolism in the organization, however, problems that include the concept of efficiency, which refer to the economic and social goals of the organization (e.g. Fitria and Sarwono, 2018; Harrington et al. 2015 and many others) are omitted.

The second part of the narrative omits or marginalizes the direct reference to the concept of P. Bourdieu. However, the context implies that it also refers to symbolic capital as the symbolic basis for a symbolic action or action. As part of these approaches, topics such as manifestations of symbolic activities (for example: Rodrigue et al., 2013; Markóczy, 2013; Kim et al., 2007), symbolic management and change management (Westphal and Zajac, 1998, 1994; Barr, 1998) are taken up, sensemaking and sensegiving (Austen and Kapias 2016; Christiansen and Varnes, 2009; Gioia and Chittipeddi, 1991) and the problem of organizational resource management (for example: De Clercq and Voronov, 2009; Zott and Huy, 2007; Ashforth and Gibbs, 1991). All these topics are analyzed from the performance point of view, often of an organizational nature, and can be included in the mainstream of narratives closely related to the organization science. The purpose of this article is related to the last group of problems. 
It is also worth mentioning here that symbolic resources are also discussed in the literature. They may be the result of symbolic actions or they may appear naturally as a result of actual activities undertaken by the organization. The purpose of this article is related to the last group of problems.

The part of literature that refers to symbolic management in relation to organizational resource problems can also be divided into two groups. The first concerns the acquisition of resources through the legitimacy of activities and processes. This part of the studies is dominated by those that relate to the acquisition of financial resources, including organizational excess in terms of financial liquidity. The second part of the literature concerns the exploitation of resources and in this case, the main issues discussed are human resources retention, the problem of leaders in the workplace, management of employee involvement and exploitation of knowledge resources. Both problem currents are described below.

\section{Symbolic management and acquisition of resources}

The acquisition of resources1 is one of the basic tasks of both a commercial organization and one that is oriented on social goals. The set of resources form the basis of organizational functioning. Therefore, the authors' interest in the role of symbolic management is significant, although views are not always supported by research results.

Conceptual elaborations have taken into account different views. The first refers to the problem of legitimacy of organizational goals and processes. Legitimacy helps attract human resources because it justifies the organization's role in the social system (Ashforth and Gibbs, 1991). Legitimacy can act also as a symbolic resource. "The intent of ceremonial conformity is to demonstrate the social congruence of the corporation to secure organizational resources such as legitimacy" (Meyer and Rowan, 1977 after: Rodrigue et al., 2013, p. 111). Organizations that incorporate societally legitimated rationalized increase their resources and through this they increase survival capabilities (Meyer and Rowan, 1977) because the legitimacy of organization attracts its members (human resources), and enables to obtain credit and funds (financial resources) (Starbuck, 1982). These views are particularly relevant to new enterprises, which

1 Due to terminological ambiguity, the author introduced a division into symbolic resources, which constitute a special group of intangible resources that strengthen the quality of other organizational resources, hereinafter referred to as "resources".

Symbolic action and organizational resources acquisition and exploitation 
are socially not recognized yet. The management of the newcomers' signals and symbolizes conforming to external expectations and establishes trust vis-à-vis potential customers, creditors, and suppliers (Gergs, 2003; De Clercq and Voronov 2009). Fostering a shared identity (as a manifestation of symbolic action) is a precursor to acquiring and leveraging resources (Webb et al., 2009). In the theoretical elaborations, attention was also paid to the role of symbolic management in the acquisition of market resources. An entrepreneur needs to create an identity for their venture that is legitimately distinctive for constructing resonant identities and motivating resource-holding audiences to allocate their resources to a venture (Ustuner and Thompson, 2010). Attaining legitimacy is important for organizations as it can lead to greater access to resources, especially relational and human (Walker and Wan, 2012).

Various types of resources were the object of the research studies, but the research material was not particularly structured. Summarizing the results of the research, there can be formulated specific conclusions about the role of symbolic action (as the basis for the generation of symbolic capital). Symbolic capital is supporting the process of developing social capital as a source of resources (Gretzinger and Royer, 2011; Kang and Park, 2016). It has been shown that symbolic actions influence investors decisions and that acquisition of financial resources is easier with use of symbolic action and symbolic assets (as good reputation) (Westphal and Zajac, 1998; Westphal and Graebner, 2010; Markoczy et al., 2013; Crilly et al., 2016; Yoo, 2017) but this impact is limited by the perception of investors by separation (Mazur and Kulczyk, 2014). There is also a question whether the availability of high-level financial resources (organizational slack), which accompanies e.g. CSR practices (Perez-Batres et al. 2012) is their effect or cause. This calls into question the unambiguous role of symbolic management in the accumulation of organizational resources. The research evidence however has indicated that entrepreneurs who are more attentive to the management of strategically important symbols are more likely to acquire resources (Zott and Huy, 2007). Entrepreneur needs to create an identity for their venture that is legitimately distinctive (symbolic action) and differentiates the venture from competitors while aligning it with the interests and values of targeted resource-holders (Überbacher et al., 2015). By this, executives engage in symbolic management to acquire material resources (public and private funding) and intangible resources (legitimacy and collaboration), especially in high-tech, innovative companies (Granqvist et al., 2013). As part of the research it has been shown also that cultural (symbolic) resources are part of the necessary conditions for the exchange and combination of knowledge (Fuller and Tian, 2006). 
The problem of the involvement of symbolic activities is of particular importance when gathering resources by social-oriented organizations. According to results of research conducted by Pache and Santos (2013), social organizations needed to display appropriateness with stakeholders as clients (final users) and industrial partners, who are embedded in a commercial logic in the process of interacting with public social services to receive the right to operate, recruit beneficiaries, and mobilize primary and additional financial resources to fund their social mission.

Summing up this part of the arguments, it can be stated that the current research indicates the benefits that can be achieved by the management of the organization in the event of the use of symbolic actions. These benefits include both the accumulation of financial and human resources.

\section{Symbolic management and resource exploitation}

As mentioned earlier, the second part of the literature concerns the role of symbolic activities in the exploitation of resources. This part of the narrative includes and in this case the results of theoretical considerations and the results of empirical research, however the latter dominate in the literature on symbolic management.

Among the conceptual approaches, it is worth mentioning the study on organizational discourse. It can be recognized as a symbolic action in which discourse influence the behavior of members and reinforces mindsets. It shapes the relations between individuals, creates mental frames and offers a great potential for social change (Galbin, 2015).

In reference to intangible assets (status, reputation, legitimacy) relation with symbolic action was also indicated. Organizational symbolic management is strengthening the unique knowledge of an organization, and also giving meaning to experience through shared awareness and understanding (Schnackenberg et al., 2019). Therefore, both market advantages resulting from unique knowledge resources are deepened and certain competitive products resulting from these strategic resources are built.

The research findings include the role of performance in exploitation of such resources as: human, (including knowledge resources) social, market and relational ones. According to results of research of Walker and Wan 2012 (p. 236-237), symbolic actions as especially greenwashing will have a negative effect on financial performance. The discussion of research starts with elaboration of McEachern (1998) who focused on manipulating of worker perceptions and 
gaining by this some performance outcomes. An employee who trusts in the right practices of the organization is able to engage in a higher degree of work and thus also improve results both individually and in groups.

A slightly different problem in the analyzed context is the problem of leadership. In the symbolic leadership dimension, the leader acts as a guide, inspirer and visionary. The results of the study by Axelsson et al. (2000) indicate that in times of transition leaders could benefit from exercising symbolic leadership and act as symbols for fundamental values and visions in the process of performance management (p.case167). In this way, employees increased their efficiency and organizations also increased results. You analyzed the problem of knowledge resources in a special way. Common language and codes operationalized through common narratives are part of the necessary conditions for sharing and combining knowledge (Fuller and Tian 2006, p. 290) and also lead to improving team results.

The symbolic capital can also enhance the performance of market resources as labels or signals. Labels act as symbolic resources and enhance the market performance of the organization (Vazquez and Gonzalez 2015a; Vazquez and Gonzalez 2015b). The signal of presence of particular CEO members can act as a symbolic resource and enhance the relational performance of the organization.

Another field of the research is related to symbolic action from the negative perspective of symbolic violence. Symbolic violence by leadership enables a more efficient human resource management (Tomlinson et al., 2013). Symbolic capital enhances short-term work performance by using certain performance indicators (which are some kind of social obligation for workers) and can in such cases be recognized as symbolic violence (Harrington et al., 2015). Knowledge-sharing performance also in some cases is a result of symbolic violence (Kamoche et al., 2014). Another study contributes to debates about the dysfunctional impacts of the use of performance measures to manage research process. It explains that the management control systems developed to resist the imposition of external performance measurement systems may lead to symbolic violence where participants become involved with their own subjugation (Agyemang and Broadbent, 2015). There exist some cases of management of employee retention caused by using symbolic capital (Brannan, 2015) which, to some extent, can be recognized also as symbolic violence. The research results revealed the role of symbolic violence in in increasing short-term efficiency but there is no research evidence, how the violence (even symbolic) influences long-term performance and value-creation system of organization. Unfortunately, these studies did not sufficiently consider the mechanism of impact on the organisation's efficiency. 
Rather, the authors try to focus on short-term performance results without indepth discussion of long-term results. This is surprising, but the concept of symbolic violence is rather perceived in a neutral way in literature.

\section{Conclusions and limitations}

To sum up the analysis, several conclusions can be made.

In both conceptual approaches and research studies, the relationship between symbolic management and the acquisition of financial, human resources (including knowledge resources) and those of a social nature (relational and market-based) was examined and demonstrated. acquiring resources can be considered that the positive side of these phenomena was usually pointed out. But Crilly et al. they noticed that firms secure resources and goodwill from external constituencies making public commitments. It can also be concluded that analyzing these commitments can be an interesting research area.

The research on the impact of symbolic management on the efficiency of resource management was conducted primarily concerning human resources. The exceptions are research on market resources (Vazquez and Gonzalez, 2015a, Vazquez and Gonzalez, 2015b) and relational (Bilgili et al. 2017, Schnackenberg et al. 2019). Perhaps this is due to the social context of social capital. In the case of the analysis of research achievements regarding the relationship between symbolic management and performance management of this resources, it can be seen that the conclusions of the research indicate both positive effects in the field of performance management as well as neutral effects and threats rather than the benefits of social violation, e.g. in the form of symbolic violence. Research indicates positive effects in the form of short-term results, but longterm dysfunctions are highlighted (such as in the case of workplace bullying (Harrington et al. 2013).

Summing up the conclusions of the analysis, it is possible to build a model (figure 1). Organizations operating in a specific environment exchange values and resources with other entities in the environment, i.e. with stakeholders (Alle \& Taug 2006). Symbolic actions are taken as a result of the need to legitimize activities and attempts to satisfy stakeholders. they constitute a source of legitimacy for the organization's activities and outside communication. Communication with the environment takes place through symbolic assets (e.g. brands). As a result of this communication, something appears that supports the organization's processes, increasing its efficiency (constituting in this way symbolic capital as assets) while generating certain symbolic obligations which 


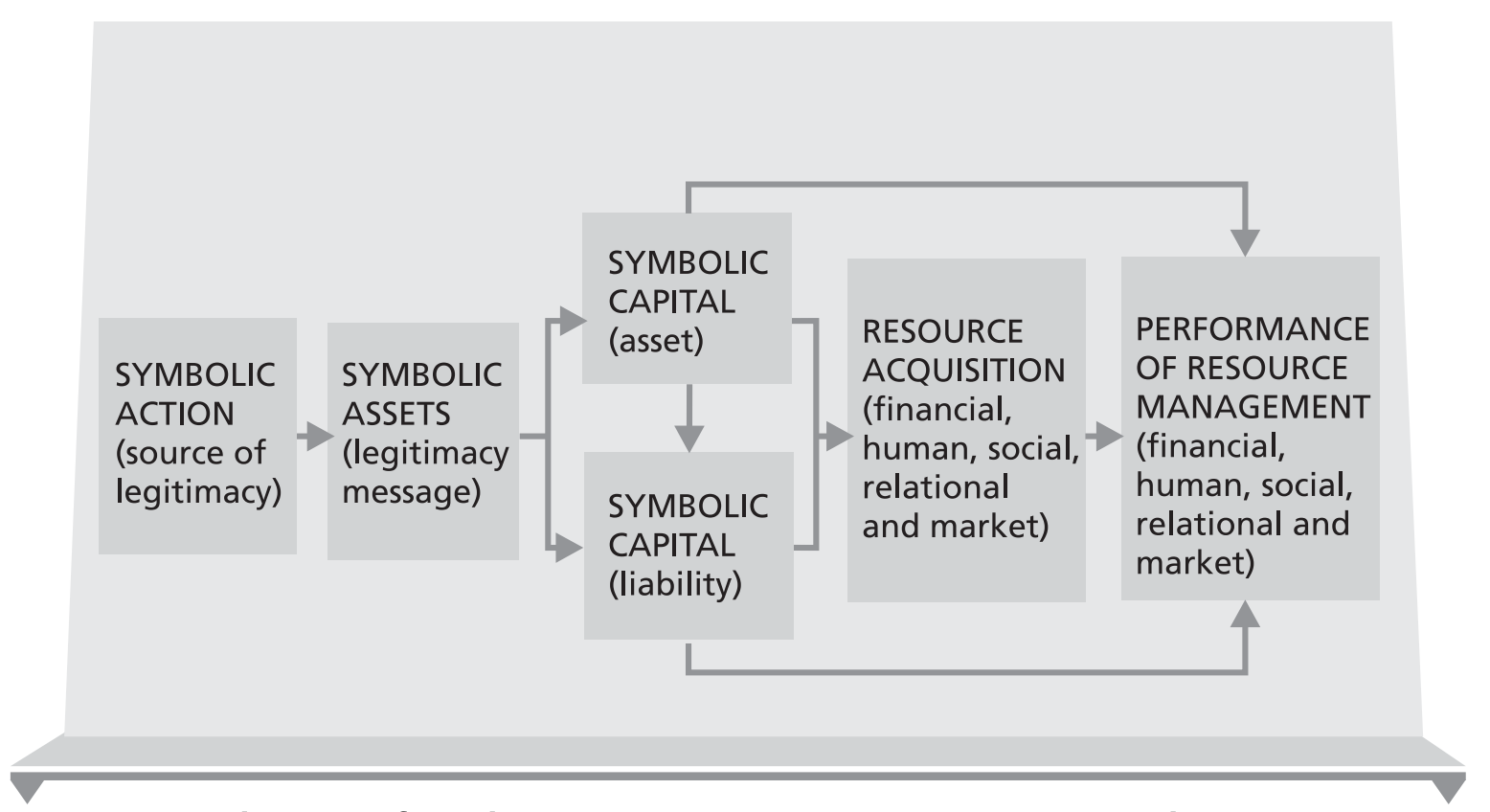

Figure 1. The role of symbolic action in resources acquisition and management

Source: own study

balances them. An interesting future research area may primarily be the problem of symbolic obligations. Referring to the theory of intellectual liabilities (Harvey and Lusch, 1999) it can be concluded that the active side of symbolic capital is balanced by symbolic obligations (fig. 1). They result from the very essence of symbolic capital, but also from the appearance of the assets themselves owned by the organization. For example, a brand that is a signal to stakeholders that the organization is adapting to their expectations means that the organization has better access to financial resources. At the same time, the declaration following the advent of the brand raises social expectations (symbolic obligations). Their fulfillment will become the basis for credibility and future effectiveness in the field of financial resources management. Lack of fulfillment will become the basis for symbolic decoupling and will reduce efficiency in the field of managing financial resources in the long run. Similarly, with the introduction of symbolic leadership. As an asset, it can be a basis for encouraging employees to cooperate and share knowledge. At the same time, it can take the form of symbolic violence, which, like any form of violence, can become dysfunctional for an organization and reduce its long-term effectiveness. That is why it is important to combine the active and passive side of symbolic capital as well as to examine their impact on the short and long-term operational efficiency of the organization. 
It is also worth paying attention to the many limitations of this material. First of all, the extremely important aspect related to the resource approach in strategic management was omitted, referring to the VRIO / VRIN analysis. This approach is appropriate for analyzing the symbolic resources of an organization and can be the basis for formulating hypotheses in terms of building and maintaining a competitive advantage, the more so because this approach very often links the problem of value with specific aspects of management. Similarly, it is also worth analyzing the problem of symbolic resources from the perspective of dynamic capabilities. The only reason for skipping such important topics is the editorial restriction of this magazine. Therefore, this type of analysis will be continued in further publications.

The next limitation of the conducted research results from the very essence of the methodology of systematic literature review. This methodology should be used to identify research niches and to determine past achievements and maturity of the research area. Therefore, the scientific discussion conducted on its basis may be considered too superficial. It points more to the state of research than leads to scientific conclusions. In-depth discussions are only made as part of a critical literature review that already allows specific generalizations and conclusions to be made. In-depth analysis is planned for the issues raised in this article in subsequent editions of this journal.

It is also worth addressing the problem of maturity of the research area. After analyzing the available articles, it can be pointed out that the research material is not sustainable because it is dominated by the problem of acquiring resources and the problem of efficiency has not yet been exhausted. First of all, this can be seen when analyzing the problem of short-term effectiveness resulting from symbolic violence, where the problem of dysfunction such as violence in the organization and its long-term effects has been virtually completely ignored. The maturity of research tools can also be assessed quite poorly. The research methods used are primarily case studies and narrative descriptions. Lack of operationalized variables, especially in relation to the management environment. However, this gives space for future research and further development of research tools.

\section{Summary}

\section{Symbolic action and organizational resources acquisition and exploitation}

The article aims to analyze the current literature (conceptual and research articles) in the field of relations between the symbolic activities of the organization and the ability to acquire 
resources and their efficient exploitation, and an attempt to build a conceptual model on this basis. This goal was achieved by applying a systematic literature review. The analysis was based on literature, both conceptual and research. Types of resources purchased by stakeholders were indicated. The study presents a conceptual model describing the role of symbolic activities in the process of resource acquisition and management. The concept of symbolic obligations was presented as a consequence of actions taken by organizations.

Keywords: symbolic activities, symbolic capital, organization resources, symbolic resources.

\section{Streszczenie}

\section{Działania symboliczne a nabywanie i eksploatacja zasobów organizacji}

Artykuł ma na celu przeanalizowanie dotychczasowej literatury (artykułów koncepcyjnych i badawczych) w zakresie relacji pomiędzy działaniami symbolicznymi organizacji a zdolnością do nabywania zasobów oraz ich efektywną eksploatacją oraz próba zbudowania modelu konceptualnego na tej podstawie. Cel ten został zrealizowany poprzez zastosowanie systematycznego przeglądu literatury. Analizę przeprowadzono na podstawie literatury, zarówno opracowań koncepcyjnych, jak badawczych. Wskazano na typy zasobów nabywanych przez interesariuszy. W opracowaniu przedstawiono konceptualny model opisujący rolę działań symbolicznych $w$ procesie nabywania zasobów oraz zarządzania nimi. Przedstawiona została koncepcja zobowiązań symbolicznych jako konsekwencji działań podejmowanych przez organizacje.

\section{Słowa}

kluczowe: działania symboliczne, kapitat symboliczny, zasoby organizacji, zasoby symboliczne.

JEL Classification: M14 


\section{References}

1. Allee, V., Taug, J. (2006). Collaboration, innovation and value creation at a global telecom, The Learning Organization, Vol. 13, Iss. 5, pp. 569-578.

2. Agyemang, G., Broadbent, J. (2015). Management control systems and research management in universities: An empirical and conceptual exploration, Accounting, Auditing \& Accountability Journal, Vol. 28, Iss. 7, pp.1018-1046

3. Ajzen, I. (1991). The theory of planned behavior, Organizational Behavior and Human Decision Processes, Vol. 50, Iss. 2, pp. 179-211.

4. Ashforth, B.E., Gibbs, B.W. (1990). The Double-Edge of Organizational Legitimation, Organization Science, Vol. 1, Iss. 2, pp. 177-194

5. Austen, A., Kapias, M. (2016). Decoupling between policy and practice through the lens of sensemaking and sensegiving, Management, Vol. 20, Iss. 1, pp. 225-238.

6. Axelsson, L., Kullen-Engström, A., Edgren, L. (2000). Management vs symbolic leadership and hospitals in transition-a Swedish example, Journal of Nursing Management, Vol. 8, Iss. 3, pp.167-173.

7. Barr, P. S. (1998). Adapting to unfamiliar environmental events: A look at the evolution of interpretation and its role in strategic change, Organization Science, Vol. 9, Iss. 6, pp. 644-669.

8. Boiral, O. (2007). Corporate Greening through ISO 14001: A Rational Myth? Organization Science, Vol. 18, Iss. 1, pp. 127-146.

9. Bourdieu, P. (1994). Rethinking the State: Genesis of Structure of the Bureaucratic Field', Sociological Theory, Vol. 12, Iss. 1, pp. 1-18.

10. Bourdieu, P. (1993). The Field of Cultural Production, Columbia University Press, New York.

11. Bourdieu, P. (1989). Social space and symbolic power, Sociological Theory, Vol. 7, Iss. 1, pp. 14-25.

12. Bourdieu, P. (1986). The forms of capital, in Richardson, J. (Ed.), Handbook of Theory and Research for the Sociology of Education, Greenwood, New York, pp. 241-258.

13. Bourdieu, P., Wacquant, L. J. D. (1992). An invitation to reflexive sociology. Chicago: University of Chicago Press.

14. Brannan, M.J. (2015). 'You're not going anywhere': employee retention, symbolic violence and the structuring of subordination in a UK-based call center, The Sociological Review, Vol. 63, Iss. 4, pp. 801-819, DOI: 10.1111/1467-954X.12312.

15. Burri, R.V. (2008). Doing Distinctions: Boundary Work and Symbolic Capital in Radiology, Social Studies of Science, Vol. 38, Iss. 1, pp. 35-62.

16. Christiansen, J.K., Varnes, C.J. (2009). Formal Rules in Product Development: Sensemaking of Structured

17. Approaches, Journal of Production Innovation Management, Vol. 26, pp. 502519. 
18. Christmann, P., Taylor, G., (2006). Firm Self-Regulation through International Certifiable Standards: Determinants of Symbolic versus Substantive Implementation, Journal of International Business Studies, Vol. 37, Iss.6, pp. 863-878.

19. Conway, S.C., McDonagh, J., Farrell, M., Kinsella, A. (2017). Uncovering obstacles: The exercise of symbolic power in the complex arena of intergenerational family farm transfer, Journal of Rural Studies, Vol. 54, Iss. 1, pp. 60-75.

20. Crilly, D., Hansen, M., Zollo, M. (2016). The grammar of decoupling. A cognitive-linguistic perspective on firms' sustainability claims and stakeholder interpretation, Academy of Management Journal, Vol. 59, Iss. 2, pp. 705-729.

21. De Clercq, D., Voronov, M. (2009). The Role of Cultural and Symbolic Capital in Entrepreneurs' Ability to Meet Expectations about Conformity and Innovation, Journal of Small Business Management, Vol. 47, Iss. 3, pp. 398-420.

22. Donaldson, L., Davies, J.H. (1991). Stewardship Theory or Agency Theory: CEO Governance and Shareholder Returns, Australian Journal of Management, Vol.16, Iss. 1, pp. 49-64.

23. Donia, M.B.L., Ronen S., Sirsly, C-A. T., Bonaccio, S. (2019). CSR by Any Other Name? The Differential Impact of Substantive and Symbolic CSR Attributions on Employee Outcomes, Journal of Business Ethics, Vol. 157, Iss. 2, pp. 503-523.

24. Fitria, A., Sarwono, B.K. (2018). Symbolic violence and the effort to silencing women in their positions as leaders (critics of the women leaders' habitus in advertising agencies), E3S Web of Conferences, Vol. 74, pp. 1-7.

25. Fuller, T., Tian, Y., (2006). Social and Symbolic Capital and Responsible Entrepreneurship: An Empirical Investigation of SME Narratives, Journal of Business Ethics, Vol. 67, Iss. 3, pp. 287-304.

26. Galbin, A. (2015). Constructing organizational discourse. Symbolic action in improving work, SEA - Practical Application of Science, Vol. 3, Iss 1(7), pp. 247-250.

27. Gergs, H-J. (2003). Economic, Social, and Symbolic Capital New Aspects for the Development of a Sociological Theory of the Market, International Studies of Management E Organization, Vol. 33, Iss. 2, pp. 22-48.

28. Gioia, D. A., Chittipeddi K., (1991). Sensemaking and sensegiving in strategic change initiation, Strategic Management Journal, Vol. 2, Iss. 6, pp. 433-448.

29. Granqvist, N., Grodal, S., Woolley, T.L. (2013). Hedging Your Bets: Explaining Executives' Market Labeling Strategies in Nanotechnology, Organization Science, Vol. 24, Iss. 2, pp. 395-413

30. Gretzinger, S., Royer S., (2011). Social and Symbolic Capital in Firm Clusters: An empirical investigation of relational resources and value 
creation, Conference paper, EMNet 2011: Fifth International Conference on Economics and Management of Networks, pp. 1-23.

31. Harrington, S., Warren, S., Rayner, C. (2016). Overcoming ethical issues through symbolic management, cultivating proponents and storytelling: the institutionalization of Korea's horseracing industry, Asia Pacific Business Review, Vol. 22, Iss. 3, pp. 439-451.

32. Hart S. (1992). An integrative framework for strategy making processes, Academy of Management Review, Vol. 17, Iss. 2, pp. 327-351.

33. Harvey, M.G., Lusch, R.F. (1999). Balancing the intellectual capital books: intangible liabilities, European Management Journal, Vol. 17, Iss. 1, pp. 85-92.

34. Jamali, D., (2010). MNCs and International Accountability Standards Through an Institutional Lens: Evidence of Symbolic Conformity or Decoupling. Journal of Business Ethics, Vol. 95, Iss. 4, pp. 617-640.

35. Kamoche, K., Kannan, S, Siebers L.Q., (2014). Knowledge-Sharing, Control, Compliance and Symbolic Violence, Organization Studies, Vol. 35, Iss. 7, pp. 989-1012.

36. Kang, S.H., Park G-S. (2016). Overcoming ethical issues through symbolic management, cultivating proponents and storytelling: the institutionalization of Korea's horseracing industry, Asia Pacific Business Review, Vol. 22, Iss. 3, pp. 439-451.

37. Kerr, R., Robinson, S. (2015). Architecture, symbolic capital and elite mobilizations: The case of the Royal Bank of Scotland corporate campus, Organization, Vol. 23, Iss. 5, pp. 699-721.

38. Kim, J.-N., Bach, S. B., Clelland, I. J. (2007). Symbolic or Behavioral Management? Corporate Reputation in High-Emission Industries, Corporate Reputation Review, Vol. 10, Iss. 2, pp. 77-98.

39. King, A. A., Lenox, M. J., Terlaak, A. (2005). The strategic use of decentralized institutions: Exploring certification

40. with the ISO 14001 management standards. Academy of Management Journal, Vol. 48, Iss. 6, pp. 1091-1106.

41. Lueg, K., Nielsen, C. (2015). Impression management as symbolic capital: an intercultural comparison of presentations by CEOs on social network sites, Communication and Language, Vol. 4, Iss. 4, pp. 88-120.

42. Markóczy, L., Li Sun, S., Peng, M.W., Shi, W., Ren B. (2013), Social network contingency, symbolic management, and boundary stretching, Strategic Management Journal, Vol. 4 Iss. 11, pp. 1367-1387.

43. Mazur, K. (2014). Zjawisko zarządzania symbolicznego a otoczenie organizacji (The Phenomenon of Symbolic Management and the Milieu of Organization), Przeglad Organizacji, Iss. 1, pp.6-11.

44. Mazur, K., Kulczyk, Z. (2014). Symboliczne rozdzielenie a decyzje inwestorów (Symbolic decoupling and investor decisions) In: Zeszyty Naukowe Uniwersytetu Szczecińskiego. Finanse, Rynki Finansowe, Ubezpieczenia, Vol. 803, Iss. 66, pp. 135-144. 
45. McEachern, R.W. (1998). Meeting Minutes as Symbolic Action, Journal of Business and Technical Communication, Vol. 12, No. 2, pp. 198-216.

46. Meyer, J. W., Rowan, B. (1977). Institutionalized organizations: Formal structure as myths and ceremony. American Journal of Sociology, Vol. 83, Iss 2, pp. 340-363.

47. Pache, A.-C., Santos, F. (2013). Inside the hybrid organization: selective coupling as a response to competing institutional logics, Acedemy of Management Journal, Vol. 56, Iss. 4, pp. 972-1001.

48. Perez-Bartes, L.A., Doh, J.P., Miller, V.V., Pisani, M. J. (2012). Stakeholder Pressure as Determinants of CSR Strategic Choice: Why do Firms Choose Symbolic Versus Substantive Self-Regulatory Codes of Conduct, Journal of Business Ethics, Vol. 110, Iss. 2, pp. 157-172.

49. Rodrigue, M., Magnan, M., Cho, C. (2013). Is Environmental Governance Substantive or Symbolic? An Empirical Investigation. Journal of Business Ethics, Vol.114, Iss. 1, pp. 107-129.

50. Schnackenberg, A. K., Bundy, J., Coen, C.A., Westphal, J.D. (2019). Capitalizing on categories of social construction: a review and integration of organizational research on symbolic strategies, Academy of Management Annals, Vol. 13, Iss. 2, pp. 375-413.

51. Singer A.E. (1994). Strategy as Moral Philosophy, Strategic Management Journal, Vol. 15, Iss. 3, pp. 191-213.

52. Starbuck, W.H. (1982), Congealing oil: inventing ideologies to justify acting ideologies out, Journal of Management Studies, Vol. 19, Iss. 1, pp. 4-27.

53. Swartz, D. (1997). Culture and Power: The Sociology of Pierre Bourdieu. Chicago, IL: University of Chicago Press.

54. Tomlinson, M., O'Reilly, D., Wallace M. (2013). Developing leaders as symbolic violence: Reproducing public service leadership through the (misrecognized) development of leaders' capitals, Management Learning

55. Vol. 44, Iss. 1, pp. 81-97.

56. Überbacher, F., Jacobs, C.D., Cornelissen, J.P., (2015). How Entrepreneurs Become Skilled Cultural Operators, Organization Studies, Vol. 36, Iss. 7., pp. 925-951

57. Walker, K., Wan, F. (2012). The Harm of Symbolic Actions and GreenWashing: Corporate Actions and Communications on Environmental Performance and Their Financial Implications, Journal of Business Ethics, Vol. 109, Iss. 2, pp. 227-242.

58. Vazquez, A.M., Gonzalez, P.A. (2015)a. Managing collective symbolic capital through agro-food labelling: Strategies of local communities facing neoliberalism in Spain, Journal of Rural Studies Vol. 41, pp. 142-152.

59. Vazquez, A.M., Gonzalez, P.A. (2015)b. Collective symbolic capital and sustainability: Governing fishing communities in a knowledge economy. 


\section{Management \\ 2019}

Vol. 23, No. 2

60. Webb J.W., Tihanyi L., Ireland R.D., Sirmin D.G., (2008). You say illegal, I say legitimate: Entrepreneurship in the informal economy, Acadaemy of Management Review, Vol. 34, Iss. 3, pp. 491-510.

61. Westphal J.D., Graebner M. (2010). A matter of appearances: how corporate leaders manage the impressions of financial analysts about the conduct of their boards, Academy of Management Journal, Vol. 53, Iss. 1, pp. 15-44.

62. Westphal, J.D., Zajac, E.J. (1994). Substance and symbolism in CEOs' longterm incentive plans, Administrative Science Quarterly, Vol. 39, Iss. 3, pp. 367-390.

63. Westphal, J.D., Zajac, E.J. (1998). The symbolic management of stockholders: corporate governance reforms and external constituent reactions, Administrative Science Quarterly, Vol. 43, Iss. 1, pp. 127-153.

64. Yoo, T. (2017). The performance dimension in symbolic management revisited: the functional role of traditional mechanisms in large Korean firms, Asia Pacific Business Review, Vol. 23, Iss. 1, pp. 116-134.

65. Zott, C., Huy Q.N. (2007). How Entrepreneurs Use Symbolic Management to Acquire Resources, Administrative Science Quarterly, Vol. 52, Iss. 1, pp. 70-105. 